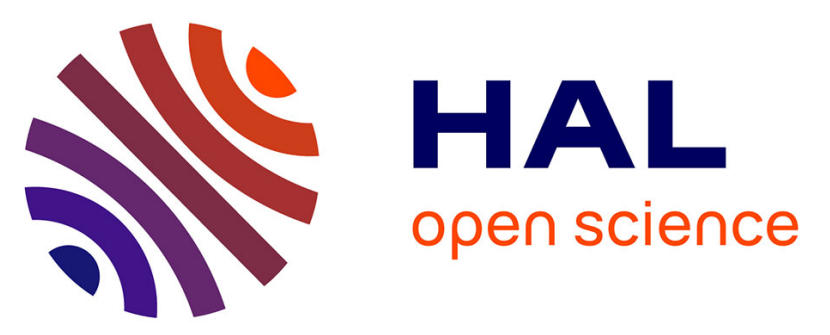

\title{
Uptake and translocation of cesium by Arabidopsis thaliana in hydroponics conditions: Links between kinetics and molecular mechanisms
}

Laure Genies, Daniel Orjollet, Loïc Carasco, Virginie Camilleri, Sandrine Frelon, Alain Vavasseur, Nathalie Leonhardt, Pascale Henner

\section{To cite this version:}

Laure Genies, Daniel Orjollet, Loïc Carasco, Virginie Camilleri, Sandrine Frelon, et al.. Uptake and translocation of cesium by Arabidopsis thaliana in hydroponics conditions: Links between kinetics and molecular mechanisms. Environmental and Experimental Botany, 2017, 138, pp.164 - 172. 10.1016/j.envexpbot.2017.03.013 . hal-01682673

\section{HAL Id: hal-01682673 \\ https://hal-amu.archives-ouvertes.fr/hal-01682673}

Submitted on 12 Jan 2018

HAL is a multi-disciplinary open access archive for the deposit and dissemination of scientific research documents, whether they are published or not. The documents may come from teaching and research institutions in France or abroad, or from public or private research centers.
L'archive ouverte pluridisciplinaire HAL, est destinée au dépôt et à la diffusion de documents scientifiques de niveau recherche, publiés ou non, émanant des établissements d'enseignement et de recherche français ou étrangers, des laboratoires publics ou privés. 
1 Uptake and translocation of cesium by Arabidopsis thaliana in hydroponics conditions: links between kinetics and molecular mechanisms

3 Laure GENIES $^{\mathrm{a}, \mathrm{b}}$, Daniel ORJOLLET ${ }^{\mathrm{a}}$, Loïc CARASCO ${ }^{a}$, Virginie CAMILLERI ${ }^{c}$, Sandrine FRELON ${ }^{c}$, 4 Alain VAVASSEUR ${ }^{\mathrm{b}}$, Nathalie LEONHARDT $^{\mathrm{b}}$, Pascale HENNER $^{\mathrm{a}}$

5 a Institut de Radioprotection et de Sûreté Nucléaire (IRSN), PRP-ENV, SERIS, Laboratoire de 6 Biogéochimie, Biodisponibilité et Transferts des radionucléides (L2BT), Cadarache, France

${ }^{b}$ Commissariat à l'Energie Atomique et aux Energies Alternatives (CEA), IBEB-SBVME, Laboratoire

8 de Biologie du Développement des Plantes (LBDP), Cadarache, France

$9{ }^{c}$ Institut de Radioprotection et de Sûreté Nucléaire (IRSN), PRP-ENV, SERIS, Laboratoire 10 d'ECOtoxicologie des radionucléides (LECO), Cadarache, France

11 Corresponding author: laure.genies@gmail.com

13 ABSTRACT

14 Early studies have shown that cesium $\left(\mathrm{Cs}^{+}\right)$competes with the macronutrient potassium $\left(\mathrm{K}^{+}\right)$for uptake by plants. The present study investigates the effect of $\mathrm{K}^{+}$supply on $\mathrm{Cs}^{+}$uptake and translocation in Arabidopsis thaliana. Taking advantage of the frequent use of this model plant in previous molecular studies, we discuss the link between functional features described for transporters involved in $\mathrm{K}^{+}$(and sometimes in $\mathrm{Cs}^{+}$) uptake and results obtained here in both $\mathrm{Cs}^{+}$influx and accumulation experiments under different $\mathrm{K}^{+}$-treatments. In low $\mathrm{K}^{+}$condition $(10 \mu \mathrm{M})$, we observed that roots affinity for $\mathrm{Cs}^{+}$increased significantly and $\mathrm{Cs}^{+}$concentration in the external medium clearly 21 affected the efficiency of $\mathrm{Cs}^{+}$uptake. Our results are consistent with previous molecular studies indicating the role of the high-affinity $\mathrm{K}^{+}$carrier AtHAK5 in $\mathrm{Cs}^{+}$uptake under $\mathrm{K}^{+}$-deprivation. Further experiments show that the lack of AtHAK5 has no more effect on $\mathrm{Cs}^{+}$uptake for external $\mathrm{Cs}^{+}$ concentration above $100 \mu \mathrm{M}$. We propose that non-selective cation channels, likely involved in $\mathrm{Cs}^{+}$ uptake under $\mathrm{K}^{+}$-sufficient conditions according to previous studies, could also mediate $\mathrm{Cs}^{+}$uptake under $\mathrm{K}^{+}$-starvation and high $\mathrm{Cs}^{+}$concentrations. Finally, evidences for $\mathrm{Cs}^{+}$translocation mediated by $\mathrm{K}^{+}$channels are discussed.

Keywords: Cesium uptake, Potassium uptake, kinetics parameters, transporters, Arabidopsis thaliana. 
Cesium $\left(\mathrm{Cs}^{+}\right)$has no known physiological role in plant but, because of its chemical similarity with the essential macronutrient potassium $\left(\mathrm{K}^{+}\right)$, the monovalent cation $\mathrm{Cs}^{+}$can be taken up from the soil solution by plant roots through the $\mathrm{K}^{+}$uptake pathway (White \& Broadley, 2000). Some biological processes involving $\mathrm{K}^{+}$can be altered by $\mathrm{Cs}^{+}$but, at the natural concentrations occurring in soil solutions, stable isotope ${ }^{133} \mathrm{Cs}$ rarely causes environmental toxicity (Hampton et al., 2004). However, radiocesium $\left({ }^{134} \mathrm{Cs}\right.$ and $\left.{ }^{137} \mathrm{Cs}\right)$, which may occur in the environment after accidental release from nuclear plant facilities or resulting of nuclear weapon tests, is a major concern. These radioisotopes emit harmful $\beta$ and $\gamma$ radiations during its decay and its uptake by plant is the predominant first step for its entry in the terrestrial food chain (Avery, 1996). In order to minimize the entry of radiocesium in the food chain, contaminated soils are usually removed from agricultural uses or managed through the elimination of contaminated surface or by using countermeasures such as fertilization with competitive cations to minimize $\mathrm{Cs}^{+}$uptake by plants (Zhu \& Shaw, 2000). Alternatively, with new biotechnologies emerging, phytoremediation is studied for contaminated site rehabilitation using plants as extractor or developing "safe" crops which do not accumulate radiocesium (Lasat \& Kochian, 1997; Kobayashi et al., 2014). The transport of monovalent cations from the soil solution to plant roots and shoots is mediated symplastically by transporters. Therefore, identification and characterization of genes encoding transporters involved in $\mathrm{Cs}^{+}$fluxes across the membranes of plant cells are thought to be helpful to understand its uptake and accumulation. Phytoextraction and development of safe crops could be optimized using plant selection based on this $\mathrm{Cs}^{+}$accumulation related knowledge (White et al., 2003). Several recent studies on the model plant Arabidopsis thaliana have deciphered part of the molecular mechanisms involved in $\mathrm{Cs}^{+}$uptake and accumulation, found among the plant $\mathrm{K}^{+}$transporters system. Since the level of $\mathrm{K}^{+}$(both in the external and intracellular medium) modifies the relative contribution of each transporters in $\mathrm{K}^{+}$fluxes (see Alemán et al., 2011 and references therein), $\mathrm{Cs}^{+}$uptake pathway also depends on the $\mathrm{K}^{+}$-status. Up to now, non-selective cation channels (NSCC) also called VoltageIndependent Cation Channels (VICC) encoded by members of the cyclic-nucleotide gated channel (AtCNGC) and glutamate like-receptor $(A t G L R)$ gene families are suspected to mediate the largest 59 part of $\mathrm{Cs}^{+}$uptake in Arabidopsis roots under $\mathrm{K}^{+}$-sufficient conditions (White \& Broadley, 2000; 60 Hampton et al., 2005). Under $\mathrm{K}^{+}$-starvation, the high-affinity transporters encoded by the 
AtKUP/HAK/KT gene families and in particular the HAK5 transporter mediate a significant part of $\mathrm{Cs}^{+}$ uptake in A. thaliana (Qi et al., 2008).

The competitive effect of $\mathrm{K}^{+}$on kinetics of $\mathrm{Cs}^{+}$uptake have been described for several crops species: barley (Middleton et al., 1960), wheat (Shaw \& Bell, 1989; Smolders et al., 1996; Zhu, 2001), maize (Sacchi et al., 1997), rice (Kondo et al., 2015), spinach (Buysse et al., 1995), radish (Prorok et al., 2016). However, only few studies report the kinetics aspect of $\mathrm{Cs}^{+}$uptake in $A$. thaliana (Broadley et al., 2001; Kanter et al., 2010) due to the fact that it is nor a commercial crop nor a potential plant for phytoremediation uses. Conversely, A. thaliana is the preferred organism for molecular studies (see above). Consequently, links between kinetics data and molecular characterization of transporters involved in $\mathrm{Cs}^{+}$uptake is reported only in few studies.

In this study, we report the effect of $\mathrm{K}^{+}$-supply on $\mathrm{Cs}^{+}$uptake, distribution and accumulation by the model plant $A$. thaliana in hydroponics condition. Links between transporters involved in $\mathrm{K}^{+}$and $\mathrm{Cs}^{+}$ uptake related-knowledge and changes observed in $\mathrm{Cs}^{+}$transport under $\mathrm{K}^{+}$-starvation are discussed.

\section{Materials and methods}

\subsection{Plant material and growing before exposure to cesium}

Arabidopsis thaliana seeds of Columbia-0 (Col-0) and athak5-3 mutant line (SALK_074868) were used in this study. As described before (Qi et al., 2008; Rubio et al., 2008), the T-DNA insertion is located in exon 4 in athak5-3. Plants homozygous for the T-DNA insertion were identified by polymerase chain reaction $(P C R)$ using primers annealing upstream (HAK5A-F1: CGCAGGAGGAACATTTGCATTGTACTC) and downstream (HAK5B-R1: AGTGCCTTTAAGACGGTAATGTCATGCTTG) of the insertion site and a T-DNA left-border primer (Lbb1.3: ATTTTGCCGATTTCGGAAC) as advised by the Salk Institute Genomic Analysis Laboratory (SIGNAL, http://signal.salk.edu/tdnaprimers.2.html).

Seeds were surface-sterilized using a mix of $70 \%$ ethanol $(\mathrm{v} / \mathrm{v}) / 0.05 \%$ SDS $(\mathrm{v} / \mathrm{v})$ and rinsed in ethanol 96\% before sowing in Petri dishes $\left(120 \mathrm{~mm}{ }^{*} 120 \mathrm{~mm}\right.$ ) on a half-strength Murashige and Skoog medium (MS1/2, Murashige \& Skoog, 1962) containing $1 \%(\mathrm{w} / \mathrm{v})$ agar and $1 \%(\mathrm{w} / \mathrm{v})$ sucrose. To synchronize germination and to break the dormancy, the sowing boxes were placed at $4^{\circ} \mathrm{C}$ during $48 \mathrm{~h}$ before transfer in a growth chamber set to $23^{\circ} \mathrm{C}, 50 \% \mathrm{HR}$ with $8 \mathrm{~h} / 16 \mathrm{~h}$ day/night cycle. After 7 days on MS1/2 agar medium, seedlings were transferred on sand (Zolux) and watered with nutrient solution 
91 to allow roots and shoots growing for a further 14 days. Finally, plants were transferred in a hydroponic system over $1 \mathrm{~L}$ of aerated nutrient solution.

93 The nutrient solution $(\mathrm{pH} 5.8)$ contained $1.1 \mathrm{mM} \mathrm{MgSO}_{4}, 805 \mu \mathrm{M} \mathrm{Ca}\left(\mathrm{NO}_{3}\right)_{2}, 2 \mathrm{mM} \mathrm{KNO}_{3}, 60 \mu \mathrm{M}$ $\mathrm{K}_{2} \mathrm{HPO}_{4}, 695 \mu \mathrm{M} \mathrm{KH} \mathrm{PO}_{4}$ and micronutrients $\left(3.6 \mu \mathrm{MnSO}_{4}, 74 \mathrm{nM}\left(\mathrm{NH}_{4}\right)_{6} \mathrm{Mo}_{7} \mathrm{O}_{24}, 3 \mu \mathrm{M} \mathrm{ZnSO}{ }_{4}, 9.25\right.$ $\mu \mathrm{M} \mathrm{H}_{3} \mathrm{BO}_{3}, 785 \mathrm{nM} \mathrm{CuSO}_{4}, 20 \mu \mathrm{M} \mathrm{Na}_{2} \mathrm{EDTA}$ and $\left.20 \mu \mathrm{M} \mathrm{FeSO}\right)_{4}$.

\subsection{Potassium treatments}

These experiments were designed to estimate the effect of $\mathrm{K}^{+}$-supply on uptake and accumulation of $\mathrm{Cs}^{+}$by $A$. thaliana. Three distinct concentrations of $\mathrm{K}^{+}(10 \mu \mathrm{M}, 100 \mu \mathrm{M}$ or $3000 \mu \mathrm{M})$ were supplied during five days before addition of $\mathrm{Cs}^{+}$in the medium.

$101 \mathrm{~K}^{+}$treatments were performed during the hydroponic step. After 3-5 days of acclimatization to hydroponics conditions with the nutrient solution described in section 2.1, plants were transferred over $1 \mathrm{~L}$ of a $\mathrm{K}^{+}$-treatment solution $(\mathrm{pH} 5.8)$ containing $0.75 \mathrm{mM} \mathrm{MgSO}_{4}, 2 \mathrm{mM} \mathrm{Ca}\left(\mathrm{NO}_{3}\right)_{2}, 0,5 \mathrm{mM}$ $\mathrm{H}_{3} \mathrm{PO}_{4}$, and micronutrients. Three different treatments were tested through adding different amounts of $\mathrm{KCl}$ in the $\mathrm{K}^{+}$-treatment solution: $10 \mu \mathrm{M}$ (starved level), $100 \mu \mathrm{M}$ (intermediate level) or $3000 \mu \mathrm{M}$ 106 (replete level).

107 In the same hydroponic box, 5-6 plants were allowed to grow over $1 \mathrm{~L}$ of $\mathrm{K}^{+}$-treatment solution during 1085 days.

\subsection{Exposure to cesium in short-term influx experiments}

111 After 30 days (+/- 3 days) of growing and $\mathrm{K}^{+}$treatment in the conditions described in sections 2.1 and

1122.2 (summarized in Table 1), seedlings were transferred into individual wells containing $8 \mathrm{~mL}$ of 113 exposure solution taking care to not contaminate shoots. The exposure solution contained the $\mathrm{K}^{+}-$ 114 treatment solution plus a range of ${ }^{133} \mathrm{Cs}$ from $0.1 \mu \mathrm{M}$ to $3000 \mu \mathrm{M}$ traced by ${ }^{137} \mathrm{Cs}$ (approximately 140 115 Bq. $\mathrm{mL}^{-1}$ representing 3.3.10 $\mathrm{\mu M} \mathrm{Cs}^{+}$). Plants were exposed during $15 \mathrm{~min}$ in order to determine 116 kinetics parameters of net influx or during $6 \mathrm{~h}$ to evaluate the evolution of $\mathrm{Cs}^{+}$distribution between 117 roots and shoots. Activities of ${ }^{137} \mathrm{Cs}$ in the exposure solution were followed during the course of assays 118 and reveal no significant depletion (data not shown).

119 After exposure to $\mathrm{Cs}^{+}$, plants were transferred in $8 \mathrm{~mL}$ of a fresh solution corresponding to the 120 exposure solution without $\mathrm{Cs}^{+}$(i.e. the $\mathrm{K}^{+}$-treatment solution) for $1 \mathrm{~min}$ to remove $\mathrm{Cs}^{+}$bound to the cell 
121 wall. Roots and shoots of plants tested were separated and blotted on Benchkote paper before 122 recording of fresh weights.

123 For each parameters (time of exposure, concentration of $\mathrm{Cs}^{+}$in the exposure solution, $\mathrm{K}^{+}$-treatment), experiments were repeated at least two times with a minimum of three plants per repetition.

\subsection{Exposure to cesium in long-term accumulation experiments}

127 Long-term accumulation experiments were performed into $1 \mathrm{~L}$ exposure solution containing the three 128 different $\mathrm{K}^{+}$-treatment solutions described in section $2.2(10,100$ or $3000 \mu \mathrm{M} \mathrm{K})$ plus $1 \mu \mathrm{M}$ stable $\mathrm{Cs}^{+}$ 129 (no tracer was used). After 30 days (+/- 3 days) of growing in the conditions described in sections 2.1 130 and 2.2 (summarized in Table 1), plants were exposed for 7 days with renewing of the exposure 131 solution every 2-3 days to avoid significant decrease of $\mathrm{Cs}^{+}$concentration in the medium due to uptake 132 by plants.

133 After 7 days exposure to $\mathrm{Cs}^{+}$, roots and shoots were harvested as described in section 2.3 for the 134 short-term influx experiments. For each $\mathrm{K}^{+}$-treatments condition, three tests were performed with a 135 minimum of five plants per test.

\subsection{Measure of cesium and potassium}

138 Fresh roots and shoots of plants were mineralized in $5 \mathrm{~mL} \mathrm{HNO}_{3} 65 \%$ and $1.5 \mathrm{~mL} \mathrm{H}_{2} \mathrm{O}_{2} 30 \%$ at 100 $139150^{\circ} \mathrm{C}$ on a sand bath. Mineralisates were evaporated to dryness and redissolved in $\mathrm{HNO}_{3} 2 \% \mathrm{v} / \mathrm{v}$ 140 before measuring the different elements.

141 Activity of ${ }^{137} \mathrm{Cs}$ accumulated in plants in the short-term experiments was measured by $\beta$ liquid 142 scintillation counting. Liquid scintillation cocktail (Instagel-Plus, Perkin Elmer) was added to the

143 mineralized samples. The photon emissions following interaction between the liquid scintillator and the

$144 \beta$ particles emitted in the radioactive decay of ${ }^{137} \mathrm{Cs}$ accumulated in plants were counted during 30 145 min. In parallel, concentration of ${ }^{137} \mathrm{Cs}$ and ${ }^{133} \mathrm{Cs}$ into the exposure solution were measured by $\beta$ liquid 146 scintillation counting and ICP-MS respectively. The amount of $\mathrm{Cs}^{+}$accumulated in plant sample was 147 deduced from the content of ${ }^{137} \mathrm{Cs}$ in plant and the ratio ${ }^{137} \mathrm{Cs} /{ }^{133} \mathrm{Cs}$ into the exposure solution.

$148{ }^{133} \mathrm{Cs}$ concentrations in roots and shoots of plants and in the exposure solutions used for the long-term 149 accumulation experiments were measured by ICP-MS. 
$\mathrm{K}^{+}$content in plants after the $\mathrm{K}^{+}$-treatments was measured by ICP-AES on a minimum of 3 non-

151 exposed samples per experiment.

\subsection{Data analysis}

154 Using data from the 15 min influx assays, we calculated a solution to plant transfer factor $\left(T F_{\text {ext } \rightarrow \text { plant }}\right)$ according to Eq.(1), defined here as the ratio between $\mathrm{Cs}^{+}$uptake by plant roots and the $\mathrm{Cs}^{+}$ concentration in the solution (named $[C s]_{e x t}$ in the following). $\mathrm{Cs}^{+}$uptake was calculated by dividing its amount in the whole plant by the roots fresh-weight (FW). This $T F_{\text {ext } \rightarrow \text { plant }}$ is a modified version of the

158 usual TF defined as the ratio between concentration in shoots and concentration in the medium.

$159 \mathrm{TF}_{\text {ext } \rightarrow \text { plant }}$ represents influx of $\mathrm{Cs}^{+}$by the plant roots depending on the external $\mathrm{Cs}^{+}$concentration.

160 Thus $T F_{\text {ext } \rightarrow \text { plant }}$ estimates the efficiency of $\mathrm{Cs}^{+}$net uptake by roots.

$T F_{\text {ext } \rightarrow \text { plant }}(C s)=\frac{(\text { Cs uptake }) \text { plant roots }}{[C s]_{\text {ext }}}$

162 As described in Zhu et al. (2000), Eadie-Hofstee plot was used to calculate the kinetics parameters

$163\left(K_{m}\right.$ and $\left.V_{\text {max }}\right)$ of $\mathrm{Cs}^{+}$influx from the 15 min experiment data. Linear regression on the range of $[C s]_{e x t}$ comprised between 0.1 and $200 \mu \mathrm{M}$ was performed on this plot, with $V=\mathrm{Cs}^{+}$uptake rate $\left(\mu \mathrm{mol} . \mathrm{g}^{-1} \mathrm{FW}\right.$ roots. $\mathrm{h}^{-1}$ ) expressed as a function of the ratio $\mathrm{V} /[\mathrm{Cs}]_{\text {ext }}$ ) according to the Eq.(2):

$V=-K_{m} \frac{V}{[C s]_{\text {ext }}}+V_{\max }$

167 Using data from the long-term accumulation experiment, we calculated a discrimination factor (DF) in order to estimate the selectivity for uptake between $\mathrm{K}^{+}$and $\mathrm{Cs}^{+}$, as described in Smolders et al. (1996)

169 and in Kanter et al. (2010):

$D F(C s)=\frac{([C s] /[K]) \text { plant }}{([C s] /[K]) \text { solution }}$

171 ANOVA analysis were performed to evaluate the effect of $\mathrm{K}^{+}$-treatment on plant $\mathrm{K}^{+}$content, fresh

172 weight and $\mathrm{Cs}^{+}$content separately (NS, Non-Significant and ${ }^{*},{ }^{* *}$, ${ }^{* * *}$ Significant at the $\alpha=0.05,0.01$

173 and 0.001 level respectively). In tables, different letters in bold indicate significant differences between means (Tuckey post-hoc test, p-value $<0.05$ ). 
3. Results and discussion

177 Effects of $\mathrm{K}^{+}$-supply on $\mathrm{Cs}^{+}$influx, accumulation and distribution was estimated using both short-term

178 (from $15 \mathrm{~min}$ to $6 \mathrm{~h}$ exposure) and 7-days exposure assays performed on $A$. thaliana (Col-0 ecotype).

179 The experiments were designed to compare the effects of three different $\mathrm{K}^{+}$-treatments on:

$180 \quad$ (i) Kinetics parameters $K_{m}$ and $V_{\max }$ for $\mathrm{Cs}^{+}$influx,

181 (ii) $\mathrm{Cs}^{+}$uptake efficiency estimated by transfer factor,

182 (iii) Distribution of $\mathrm{Cs}^{+}$between roots and shoots.

183 Role of the high-affinity $\mathrm{HAK} \mathrm{K}^{+}$carrier in $\mathrm{Cs}^{+}$uptake under both low and high $\mathrm{K}^{+}$-supply is also 184 described for a range of $\mathrm{Cs}^{+}$external concentrations ([Cs] $\left.]_{\text {ext }}\right)$.

185

\subsection{Effect of $K^{+}$-treatment on plants potassium content and on plant growth}

187 Early studies have shown that $\mathrm{K}^{+}$content of plant affects uptake of monovalent cations (Kochian \& 188 Lucas, 1982). In order to evaluate the effect of $\mathrm{K}^{+}$-supply on $\mathrm{Cs}^{+}$uptake, 25 days-old plants were first 189 acclimated during five days to three distinct levels of $\mathrm{K}^{+} . \mathrm{K}^{+}$content of plants after acclimation is 190 significantly different between the three distinct $\mathrm{K}^{+}$-treatments (Table 2): plant $\mathrm{K}^{+}$content is 1.5 times 191 higher for $\mathrm{K}^{+}$-replete seedlings $\left(3000 \mu \mathrm{M} \mathrm{K}^{+}\right.$condition) compared to the $\mathrm{K}^{+}$-starved conditions (10 $\mu \mathrm{M}$ $\left.192 \mathrm{~K}^{+}\right)$.

193 However, we did not observe visible $\mathrm{K}^{+}$starvation symptoms like chlorosis of older leaves nor plant 194 growth effects (Table 2). Plants were growing in standard $\mathrm{K}^{+}$condition (2 mM) before $\mathrm{K}^{+}$-treatments 195 were applied. As stated by Kanter et al. (2010), this pre-culture in sufficient $\mathrm{K}^{+}$conditions can prevent 196 the further effects of turning to low $\mathrm{K}^{+}$supply.

197 Plants were exposed to $\mathrm{Cs}^{+}$after acclimation period with the three different $\mathrm{K}^{+}$-supplies. The level of

$198 \mathrm{~K}^{+}$during the pre-treatment was maintained in the exposure solution containing $\mathrm{Cs}^{+}$. Thus, our 199 experiments describe the effect of global level of $\mathrm{K}^{+}$-supply i.e. in the solution outside the plants during 200 the exposure to $\mathrm{Cs}^{+}$but also inside the plants due to the $\mathrm{K}^{+}$-treatment in pre-culture. efficiency 
204 Effects of $[C s]_{e x t}$ on transfer factor for the three $\mathrm{K}^{+}$-conditions are shown in Figure 1. As expected, $205 T F_{\text {ext } \rightarrow \text { plant }}$ values (calculated as described in Eq.(1)) are higher for plants in the $10 \mu \mathrm{M} \mathrm{K}$-condition 206 compare to the $\mathrm{K}^{+}$-replete plants (between 17 and 1.6 times higher, depending on the $[C s]_{e x t}$ ). As 207 stated before (Waegeneers et al., 2001), there are different reasons to record a higher $\mathrm{Cs}^{+}$transfer 208 factor in low $\mathrm{K}^{+}$condition:

209 i) the high depletion of $\mathrm{K}^{+}$at the root surface due to high demand of plant to sustain growth 210 whereas $\mathrm{K}^{+}$is weakly available. This depletion of $\mathrm{K}^{+}$in the medium favors $\mathrm{Cs}^{+}$uptake.

211 ii) the higher uptake rate potential of $\mathrm{Cs}^{+}$at low $\mathrm{K}^{+}$due to prevalence of high-affinity transport 212 (HAT) system. In A. thaliana, this HAT system is mainly mediated by HAK5 which is known to be involved in $\mathrm{Cs}^{+}$uptake (Rubio et al., 2000, Qi et al., 2008).

214 When cultured in low $\mathrm{K}^{+}$condition $\left(10 \mu \mathrm{M} \mathrm{K}^{+}\right)$, the plasma membrane potential of $A$. thaliana roots 215 cells (in the resting state) can become as negative as $-215 \mathrm{mV}$ (Hirsch et al., 1998). In these conditions, $\mathrm{K}^{+}$uptake is mainly mediated by high-affinity carriers that move $\mathrm{K}^{+}$against the 217 electrochemical gradient. In maize, it has been shown that these carriers display low selectivity between $\mathrm{K}^{+}$and $\mathrm{Cs}^{+}$(Sacchi et al., 1997). Activity of low selective carriers, by contrast with highly selective transport system, should display strong sensitivity to $\mathrm{K}^{+} / \mathrm{Cs}^{+}$competition in the external medium. This could explain why increase in $\mathrm{K}^{+} / \mathrm{Cs}^{+}$competition with increasing $[K]_{\text {ext }}$ in the low concentration range (between $10 \mu \mathrm{M}$ and $100 \mu \mathrm{M} \mathrm{K}^{+}$-conditions in this study) results in significant decrease of $\mathrm{Cs}^{+}$transfer factor (Figure 1).

223 Efficiency of $\mathrm{Cs}^{+}$uptake also depends on the $[\mathrm{Cs}]_{\text {ext }}$. Thus, $T F_{\text {ext } \rightarrow \text { plant }}$ decreases with increasing $\mathrm{Cs}^{+}$in 224 the external solution (Figure 1). Linear regression indicates that this effect is significant $(p<0.01)$ for 225 the $10 \mu \mathrm{M}$ and $100 \mu \mathrm{M} \mathrm{K}^{+}$condition with adjusted- $R^{2}$ between 0.91 and 0.83 respectively. This could 226 be due to the behavior of carriers which became saturated because conformational changes are 227 needed for each transport event. As a consequence of transporters saturation, efficiency of $\mathrm{Cs}^{+}$ 228 uptake (and thus $T F_{\text {ext } \rightarrow \text { plant }}$ ) could be reduced with the $[C s]_{\text {ext }}$ increasing. Membrane depolarization 229 due to the cation $\mathrm{Cs}^{+}$accumulation in root cells and due to the fact that $\mathrm{Cs}^{+}$blocks some of the $\mathrm{K}^{+}$ 230 channels should also be addressed as a hypothesis to explain this observation. Indeed, lower 231 membrane potential reduces the driving force for positively charged element and subsequently 232 reduces $\mathrm{Cs}^{+}$uptake as described previously for an Arabidopsis mutant disrupted in a plasma 233 membrane proton pump (Haruta \& Sussman, 2012). 
234 When $[K]_{\text {ext }}$ increases $(>100 \mu \mathrm{M})$, the electrochemical gradient is reduced (Hirsch et al., 1998) and the 235 membrane potential follows the Nernst potential of $\mathrm{K}^{+}$(Hedrich, 2012). In these conditions, $\mathrm{K}^{+}$uptake 236 is mainly mediated by channels. For higher $\mathrm{K}^{+}$levels in this study $(100 \mu \mathrm{M}$ and $3000 \mu \mathrm{M})$, we observed only a slight decrease of $T F_{\text {ext } \rightarrow \text { plant }}$ value with the increase of $[C s]_{\text {ext }}$ which is consistent with

238 a channel-type transport system: when the pore is open, no more conformational changes are needed 239 to transport ions. Therefore, saturation pattern are not observed conversely to carrier-mediated 240 pathway.

241 Eadie-Hofstee plots (Eq.(2)) derived from data of the $15 \mathrm{~min}$ influx experiments are presented in 242 Figure 2. The non-linear pattern of these plots let us to distinguish at least two systems for $\mathrm{Cs}^{+}$uptake 243 depending on the $[C s]_{\text {ext }}$. In the range of $[C s]_{\text {ext }}$ comprised between 0.1 and $200 \mu \mathrm{M}$, kinetics 244 parameters (Table 3) were estimated by linear regression on the Eadie-Hofstee plots for the three $\mathrm{K}^{+}$conditions. In $\mathrm{K}^{+}$-starved plants (10 $\mu \mathrm{M} \mathrm{K}^{+}$-supply), we observed a drastic reduction of $K_{m}$ that signs a higher affinity of the roots transport system for $\mathrm{Cs}^{+}$. The slight increase of $V_{\max }$, which represent maximal rate of $\mathrm{Cs}^{+}$influx when the uptake system is saturated, can be interpreted as a higher number of transporters with ability to transport $\mathrm{Cs}^{+}$in the low- $\mathrm{K}^{+}$condition. The well-known positive regulation of high-affinity transporters encoding gene expression, in particular AtHAK5, by low $\mathrm{K}^{+}$supply likely contributes to this effect of $\mathrm{K}^{+}$on both $K_{m}$ and $V_{\max }$. Additionally, early study in excised roots of winter wheat (Shaw \& Bell, 1989) described a dual uptake mechanism for $\mathrm{Cs}^{+}$uptake in the global highaffinity range $\left([C s]_{\text {ext }}\right.$ below $\left.200 \mu \mathrm{M}\right)$. The high-affinity HAK5 carrier contributing in this dual uptake system specifically for low $\mathrm{K}^{+}$condition, this could explain the lower $\mathrm{R}^{2}$ obtained for $\mathrm{K}^{+}$-starved plants 254 in our experiments (Table 3 ).

\subsection{Distribution of cesium in roots and shoots}

\subsubsection{Short-term cesium uptake experiment: evolution of cesium distribution with time and with} $[\mathrm{Cs}]_{\text {ext }}$

Distribution of $\mathrm{Cs}^{+}$between roots and shoots (related to fresh weight) after $15 \mathrm{~min}$ and $6 \mathrm{~h}$ exposure

260 for the three $\mathrm{K}^{+}$-conditions and a range of $[C s]_{e x t}$ are shown in Figure 3. $\mathrm{Cs}^{+}$root:shoot concentration 261 ratio decreased rapidly over time. Thus ratios after $6 \mathrm{~h}$ exposure are in average 5 to 10 times lower 262 than after 15 min exposure, depending on the $\mathrm{K}^{+}$-treatment. We also found that, on average, $30 \%$ of the total quantity of $\mathrm{Cs}^{+}$was found in shoots after only $15 \mathrm{~min}$ of exposure in the highest $\mathrm{K}^{+}$-conditions 
264 (data not shown) suggesting that $\mathrm{Cs}^{+}$is highly mobile in these conditions. In contrast, $\mathrm{Cs}^{+}$root:shoot 265 concentration ratio is up to ten times higher for $\mathrm{K}^{+}$-starved plant compared to the highest $\mathrm{K}^{+}$-conditions 266 and between 3 and $20 \%$ of $\mathrm{Cs}^{+}$were found in shoots in this condition depending on [Cs] ext. 267 Interestingly, $[\mathrm{Cs}]_{\text {ext }}$ seems to affect $\mathrm{Cs}^{+}$root:shoot concentration ratio only for the $10 \mu \mathrm{M} \mathrm{K}^{+}$-condition. 268 In this condition, translocation of $\mathrm{Cs}^{+}$from the root to the shoot is higher when $[\mathrm{Cs}]_{\text {ext }}$ increases.

269 These data suggest that $\mathrm{Cs}^{+}$translocation is mediated by very efficient systems which could be 270 inhibited by decrease of $\mathrm{K}^{+}$and improved when $\mathrm{Cs}^{+}$concentrations increase in low $\mathrm{K}^{+}$condition.

\subsubsection{Long-term cesium accumulation experiment}

$273 \mathrm{Cs}^{+}$accumulation in roots and shoot tissues after 7 days exposure to $1 \mu \mathrm{M} \mathrm{Cs}^{+}$is given in Table 4 for 274 the three $\mathrm{K}^{+}$-treatments. The $\mathrm{Cs}^{+}$root:shoot concentration ratio is $8.9(\mathrm{SD}=0.8), 1.6(\mathrm{SD}=0.4)$ and 0.9 $275(\mathrm{SD}=0.2)$ in the $10 \mu \mathrm{M}, 100 \mu \mathrm{M}$ and $3000 \mu \mathrm{M} \mathrm{K}^{+}$-condition respectively. For the highest $\mathrm{K}^{+}$-conditions, 276 these values are comparable with the root:shoot concentration ratio obtained after $6 \mathrm{~h}$ exposure to 1 $277 \mu \mathrm{M}$ Cs suggesting that equilibrium between roots and shoot $\mathrm{Cs}^{+}$content occurs quickly during the first 278 hours. This equilibrium between $\mathrm{Cs}^{+}$concentrations in roots and shoots likely involves both 279 translocation and recirculation mechanisms. Indeed, previous study on $\mathrm{Cs}^{+}$circulation in spinach 280 indicates that about $85 \%$ of $\mathrm{Cs}^{+}$accumulated in shoots is recirculating to the roots under certain 281 conditions (Buysse et al., 1995).

282 As in short-term influx experiments, fresh weight-based $\mathrm{Cs}^{+}$concentration remains globally higher in 283 roots than in shoots of Col-0. This result is consistent with previous studies on different plant species 284 (see the review by Zhu \& Smolders (2000)) but reasons for higher $\mathrm{Cs}^{+}$accumulation in roots than in 285 shoots remain unclear. As far as we know, limitation of $\mathrm{Cs}^{+}$storage in the vacuole which could 286 enhance recirculation from the shoots to the roots has not been proven yet. Another explanation is 287 that $\mathrm{Cs}^{+}$adsorbed on the root surface could be a factor of discrepancies between roots and shoot $\mathrm{Cs}^{+}$ 288 concentration. Roots are exposed to external $\mathrm{Cs}^{+}$whereas $\mathrm{Cs}^{+}$in shoots comes from roots only. 289 Furthermore, some authors suggest that larger amount of $\mathrm{Cs}^{+}$distributes in cell wall (and free space) 290 at low external $\mathrm{K}^{+}$concentration due to lower competition for adsorption site on the root surface (Zhu 291 et al., 1999). This could explain why differences between $\mathrm{Cs}^{+}$roots and shoot concentrations are 292 reduced when external $\mathrm{K}^{+}$concentration increases. 
$\mathrm{K}^{+}$and $\mathrm{Cs}^{+}$do not display the same distribution pattern: shoots contain around $75 \%$ of the total 294 amount of $\mathrm{K}^{+}$whereas shoots contain between 25 and $80 \%$ of the total amount of $\mathrm{Cs}^{+}$depending on 295 the $\mathrm{K}^{+}$-treatment (Figure 4). When plants are $\mathrm{K}^{+}$-starved, $\mathrm{Cs}^{+}$distribution highly differs from $\mathrm{K}^{+}$ 296 distribution.

297 In accordance with others studies on different plant species (Buysse et al., 1996), we observed that 298 the $\mathrm{Cs}^{+}$root:shoot concentration ratio in $A$. thaliana is higher when plants are $\mathrm{K}^{+}$-starved. By analogy 299 with adjustment of $\mathrm{K}^{+}$distribution under low- $\mathrm{K}^{+}$supply condition in $A$. thaliana, the decrease of the part 300 of total $\mathrm{Cs}^{+}$allocated to the shoots could be the result of two distinct mechanisms:

301 (i) Limitation of $\mathrm{Cs}^{+}$loading in xylem for translocation from roots to the shoots. The $\mathrm{K}^{+}$-outward 302 rectifying channel SKOR, expressed in root stellar tissues (pericycle and xylem parenchyma) and mediating $\mathrm{K}^{+}$loading into the xylem sap (Gaymard et al., 1998), is down-regulated by low external $\mathrm{K}^{+}$concentration (Pilot et al., 2003). Subsequently, loading of $\mathrm{K}^{+}$in the xylem is reduced in low- $\mathrm{K}^{+}$condition. Expressed in Xenopus oocytes, AtSKOR displays a permeability to $\mathrm{Cs}^{+}$(Gaymard et al., 1998) but its role in $\mathrm{Cs}^{+}$transport remains unknown Taking these previous findings with distribution pattern of $\mathrm{Cs}^{+}$described here, it is tempting to speculate that inhibition of SKOR at low- $\mathrm{K}^{+}$could also limit $\mathrm{Cs}^{+}$transport from roots to shoots. It is worth pointing out that modifications of internal $\mathrm{K}^{+}$fluxes with external $\mathrm{K}^{+}$concentrations are not significant in our experiments maybe due to the high $\mathrm{K}^{+}$content of the plant before treatment with low-K $\mathrm{K}^{+}$supply.

(ii) Higher redistribution of $\mathrm{Cs}^{+}$from the shoots to the roots via the phloem sap.

313 The decrease of $\mathrm{Cs}^{+}$allocated to the shoots in low- $\mathrm{K}^{+}$condition could also be linked to the global 314 increase of $\mathrm{Cs}^{+}$content in plant. Indeed, preferential distribution in roots when plants accumulate high 315 amount of $\mathrm{Cs}^{+}$might reflect the limit of $\mathrm{Cs}^{+}$storage and/or translocation in shoots together with the 316 part of $\mathrm{Cs}^{+}$adsorbed in roots mentioned above which is not available for translocation and which is 317 taking account in roots $\mathrm{Cs}^{+}$concentration calculation.

\subsection{Discrimination between potassium and cesium}

320 Discrimination factor (DF, Eq.(3)) values calculated for plants from the long-term exposure 321 experiments are less than unity whatever the external $\mathrm{K}^{+}$level (Table 4), which means that in any case $322 \mathrm{~K}^{+}$is more efficiently absorbed than $\mathrm{Cs}^{+}$, as shown in most previous studies (Zhu \& Smolders, 2000 
323 and references therein). $D F(C s)$ is significantly lower for the $10 \mu \mathrm{M} \mathrm{K}^{+}$-condition indicating a stronger 324 discrimination against $\mathrm{Cs}^{+}$for $\mathrm{K}^{+}$-starved plant. Interestingly, if only one system involved in $\mathrm{K} / \mathrm{Cs}$ 325 uptake operated for all $\mathrm{K}^{+}$concentrations with a constant selectivity, we would have a reduction of discrimination against $\mathrm{Cs}^{+}$at low $\mathrm{K}^{+}$level due to the lowest competition between the two in the external medium. Decrease of discrimination against $\mathrm{Cs}^{+}$for lower $\mathrm{K}^{+}$level was observed for spring wheat (Smolders et al., 1996) but previous study on $A$. thaliana indicates the same result that we obtained here. Thereby, Kanter et al. (2010) recorded higher discrimination against $\mathrm{Cs}^{+}$for the lowest $330 \mathrm{~K}^{+}$concentration.

331 A part of the effects of $\mathrm{K}^{+}$-supply on plant $D F(C s)$ can be imputed on the plural $\mathrm{Cs}^{+}$uptake system 332 involving transporters with different selectivity and with activity regulated by $\mathrm{K}^{+}$concentrations and 333 membrane potential. For example, $\mathrm{K}^{+}$deprivation affects positively expression of AtHAK5 gene which 334 is a major contributor to $\mathrm{K}^{+}$uptake under very low and low- $\mathrm{K}^{+}$conditions and a major pathway for $\mathrm{Cs}^{+}$ 335 uptake in certain conditions.

336 It has been proposed that, conversely to channels functioning at high level of $\mathrm{K}^{+}$, high-affinity carriers 337 should display low discrimination against $\mathrm{Cs}^{+}$(Zhu, 2001). It is worth pointing out that, in our 338 experiments, the $D F(C s)$ value is lower for $\mathrm{K}^{+}$-starved plants indicating a higher discrimination against $339 \mathrm{Cs}^{+}$at low level of $\mathrm{K}^{+}$. From a molecular point of view, this result remains unclear. Otherwise, we think 340 that the calculation of $D F(C s)$ could be affected by bias. $\mathrm{K}^{+}$-content of plants tested results from 25 341 days of culture in sufficient $\mathrm{K}^{+}$supply prior to $\mathrm{K}^{+}$-treatments. This pre-culture in sufficient- $\mathrm{K}^{+}$conditions 342 could lead to a $\mathrm{K}^{+}$-content higher than expected for plants supplied with $10 \mu \mathrm{M} \mathrm{K}^{+}$and therefore a ratio $343([\mathrm{Cs}] /[\mathrm{K}])$ plant "underestimated". Potential differences in $\mathrm{Cs}^{+} / \mathrm{K}^{+}$ratio at the root surface compared to 344 bulk solution as a resultant of uptake kinetics of both species should also be addressed as factor of 345 discrepancy as stated in Smolders et al. (1996).

\subsection{Comparison between athak5-3 mutant line and Col-0 wildtype}

348 We used a T-DNA insertion line in AtHAK5 to study the effect of $[C s]_{\text {ext }}$ and $[K]_{\text {ext }}$ on HAK5-mediated $349 \mathrm{Cs}^{+}$influx. PCR amplification as described in the Material and Method section confirmed the 350 homozygosity of the T-DNA insertion in the mutant line used.

351 No significant differences on $\mathrm{Cs}^{+}$influx between athak5-3 mutant line and Col-0 wildtype were 352 detected for $\mathrm{K}^{+}$-replete plants $\left(3000 \mu \mathrm{M} \mathrm{K}^{+}\right.$-condition, Figure $\left.5-\mathrm{B}\right)$. This result can be explained by the 
expression pattern of HAK5 which is up-regulated by $\mathrm{K}^{+}$-starvation and down-regulated after $\mathrm{K}^{+}$354 resupply (Armengaud et al., 2004).

355 As expected for $\mathrm{K}^{+}$-starved plant $\left(10 \mu \mathrm{M} \mathrm{K}^{+}\right.$-condition, Figure $\left.5-\mathrm{A}\right), \mathrm{Cs}^{+}$uptake is lower in the athak5-3 356 mutant due to the lack of HAK5 transporter. However, significant differences between athak5-3 mutant 357 and Col-0 disappear for high concentration of $\mathrm{Cs}^{+}$. According to the data, between $76 \%$ and $69 \%$ of 358 the total $\mathrm{Cs}^{+}$uptake is mediated by HAK5 pathway for $1 \mu \mathrm{M}$ and $10 \mu \mathrm{M}[\mathrm{Cs}]_{\text {ext }}$ while contribution of 359 HAK5 to $\mathrm{Cs}^{+}$uptake is negligible for high external $\mathrm{Cs}^{+}$concentration (above $200 \mu \mathrm{M}$ ). In short-term 360 uptake experiments on 14 days-old seedlings, Qi et al. (2008) measure only a $20 \%$ decrease of $\mathrm{Cs}^{+}$ 361 influx in hak5 mutants compare to wildtype. Based on result obtained here, this may be partly due to 362 the high $[C s]_{\text {ext }}(50 \mu \mathrm{M})$ they applied during the influx assay (with $500 \mu \mathrm{M}$ of $\mathrm{K}^{+}$supply). In long-term 363 exposure experiments (7 days) under $\mathrm{K}^{+}$-sufficient conditions, it has been shown that $\mathrm{Cs}^{+}$induces 364 AtHAK5 expression maybe due to $\mathrm{K}^{+}$-deficiency caused by $\mathrm{Cs}^{+}$(Adams et al., 2013) and, up to now, $365 \mathrm{Cs}^{+}$has not been shown to inhibit HAK5 transporter. Therefore, specific blockade of HAK5-mediated 366 pathway for $\mathrm{Cs}^{+}$uptake when $[\mathrm{Cs}]_{e x t}$ is high remains unclear. Conversely, we think that other systems 367 involved in $\mathrm{Cs}^{+}$uptake, which can be efficient under low- $\mathrm{K}^{+}$and high-Cs ${ }^{+}$conditions, may exist. These 368 systems operating at high $[C s]_{e x t}$ could mediate $\mathrm{Cs}^{+}$uptake in athak5-3 mutant and explain why we do 369 not observe differences between plants lacking HAK5 and wildtype under this condition.

370 Several studies indicate that Non-Selective Cation Channels (NSCC) (also named Voltage371 Independent Cation Channels, VICC, and encoding by CNGC and GLR genes) are very promising 372 candidates for channel-mediated $\mathrm{Cs}^{+}$transport pathway (White \& Broadley, 2000 and references 373 therein; Hampton et al., 2005). According to the model described by White and Davenport (2002) for 374 permeation of monovalent cations through the VIC channels, at most two cations can bind 375 simultaneously and interact within the pore. Applied to $\mathrm{Cs}^{+}$and $\mathrm{K}^{+}$, these interactions can result in the 376 inhibition of $\mathrm{Cs}^{+}$influx by $\mathrm{K}^{+}$and therefore, this model predicts the greatest $\mathrm{Cs}^{+}$influx through $\mathrm{VIC}$ 377 channels when $[K]_{\text {ext }}$ is low and $[C s]_{\text {ext }}$ is high (White \& Broadley, 2000). This pattern is consistent with 378 the system described above to explain the athak5-3 mutant and wildtype convergence with increasing 379 external $\mathrm{Cs}^{+}$concentration.

380 In Arabidopsis, HAK5 gene belongs to the HAK/KUP/KT family with 12 other genes (Mäser et al., 381 2001). The knowledge about their role in $\mathrm{Cs}^{+}$and $\mathrm{K}^{+}$transport is still fragmentary but there are some 382 very promising candidates for $\mathrm{Cs}^{+}$pathway. Besides AtHK5, AtKUP9 expressed in E. coli mediates 
$383 \mathrm{Cs}^{+}$transport (Kobayashi et al., 2010). Further investigations are thus needed to understand the role 384 of each HAK/KUP/KT transporter but up to now this family appears as the dominant $\mathrm{Cs}^{+}$transport 385 pathway for $A$. thaliana under low-K $\mathrm{K}^{+}$supply.

\section{Conclusions}

388 As for $\mathrm{K}^{+}$uptake, $\mathrm{Cs}^{+}$transport is mediated by both carriers and channels. Under low $\mathrm{K}^{+}$condition (10 $389 \mu \mathrm{M})$, we measured an increase of the affinity (calculated using Michaelis-Menten equation) of 390 Arabidopsis thaliana roots for $\mathrm{Cs}^{+}$. Additionally we observed a decrease of the transfer factor 391 calculated for $\mathrm{Cs}^{+}$with $\mathrm{Cs}^{+}$increasing in the external medium. This result about the effect of $\mathrm{Cs}^{+}$ concentration on $\mathrm{Cs}^{+}$uptake efficiency suggests that different mechanisms operate depending on $\mathrm{Cs}^{+}$ 393 concentration in the medium or/and mechanisms operating at low-Cs ${ }^{+}$external concentration are 394 saturated at high $\mathrm{Cs}^{+}$concentration.

395 Taking together, results on affinity and transfer factor are consistent with the known $\mathrm{Cs}^{+}$uptake mediated by the high-affinity $\mathrm{K}^{+}$carrier AtHAK5 under $\mathrm{K}^{+}$-starvation. Testing a mutant lacking this

397 carrier, we found that discrepancies between wildtype and athak5-3 disappear when $\mathrm{Cs}^{+}$in the 398 external medium is high (above $100 \mu \mathrm{M}$ ). Based on predicted functioning of this type of channels, we 399 suggest that non-selective cation channels could mediate $\mathrm{Cs}^{+}$influx in low $\mathrm{K}^{+}$condition and high 400 external $\mathrm{Cs}^{+}$concentrations.

401 Affinity of $A$. thaliana roots for $\mathrm{Cs}^{+}$did not change substantially between intermediate and high level of $402 \mathrm{~K}^{+}(100$ and $3000 \mu \mathrm{M})$. Varying the $\mathrm{Cs}^{+}$concentration in the external medium, we found that $\mathrm{Cs}^{+}$has 403 no significant effect on transfer factor calculated for $\mathrm{Cs}^{+}$when $\mathrm{K}^{+}$is high. These results are consistent 404 with the supposed channel-mediated pathway for $\mathrm{Cs}^{+}$uptake under $\mathrm{K}^{+}$-sufficient conditions.

405 Studying the effect of $\mathrm{K}^{+}$-supply on $\mathrm{Cs}^{+}$distribution between roots and shoots, we found that the part 406 of $\mathrm{Cs}^{+}$allocated to the shoots was lower under $\mathrm{K}^{+}$-deprivation. As the total $\mathrm{Cs}^{+}$accumulated into the 407 plant is higher in this condition, a part of the impairment of $\mathrm{Cs}^{+}$translocation could be explained by a 408 limitation of $\mathrm{Cs}^{+}$storage into shoots. Additionally, we suggest that inhibition of SKOR-mediated $\mathrm{K}^{+}$ 409 translocation at low- $\mathrm{K}^{+}$supply could also limit $\mathrm{Cs}^{+}$translocation. However, further experiments on skor 410 Arabidopsis mutant for example are needed to better understand the role of $\mathrm{K}^{+}$channels in $\mathrm{Cs}^{+}$ 411 translocation. 
412 Finally, recent identification of transporters involved in $\mathrm{Cs}^{+}$uptake and functional studies on $\mathrm{K}^{+}$

413 transporters let us to discuss kinetics data in a molecular and mechanistic way. The understanding of 414 mechanisms leading to $\mathrm{Cs}^{+}$uptake by plants is essential for modelling approaches to predict the 415 success of phytoremediation strategies for example. However, beside the plant part, integration of the 416 soil part to predict $\mathrm{K}^{+}$and $\mathrm{Cs}^{+}$concentration around the roots is also needed for a higher accuracy of 417 these modelling approaches.

418

\section{Acknowledgments}

420 This work was conducted within a PhD cofunded by IRSN and CEA and has benefited from funds of 421 the French government, managed by the Agence Nationale de la Recherche, originating from the 422 funding program "Investissement d'Avenir" under the reference ANR-11-RSNR-0005.

\section{References}

Adams, E., Abdollahi, P., Shin, R., 2013. Cesium inhibits plant growth through jasmonate signaling in Arabidopsis thaliana. Int. J. Mol. Sci. 14, 4545-59.

Alemán, F., Nieves-Cordones, M., Martínez, V., Rubio, F., 2011. Root K+ acquisition in plants: the Arabidopsis thaliana model. Plant Cell Physiol. 52, 1603-12.

Armengaud, P., Breitling, R., Amtmann, A., 2004. The potassium-dependent transcriptome of Arabidopsis reveals a prominent role of jasmonic acid in nutrient signaling. Plant Physiol. 136,

434 Broadley, M.R., Escobar-Gutiérrez, A.J., Bowen, H.C., Willey, N.J., White, P.J., 2001. Influx and 2556-76. accumulation of $\mathrm{Cs}+$ by the akt1 mutant of Arabidopsis thaliana (L.) Heynh. lacking a dominant $\mathrm{K}+$ transport system. J. Exp. Bot 52, 839-44.

Buysse, J., Van den Brande, K., Merckx, R., 1995. The distribution of radiocesium and potassium in spinach plants grown at different shoot temperatures. J. Plant Physiol. 146, 263-267. distribution of radiocaesium in plants. Plant Soil 178, 265-71. 
Deeken, R., Geiger, D., Fromm, J., Koroleva, O., Ache, P., Langenfeld-Heyser, R., Sauer, N., May, S.T., Hedrich, R., 2002. Loss of the AKT2/3 potassium channel affects sugar loading into the phloem of Arabidopsis. Planta 216, 334-44.

Gaymard, F., Pilot, G., Lacombe B, Bouchez, D., Bruneau, D., Boucherez, J., Michaux-Ferrière, N., Thibaud, J.-B., Sentenac, H., 1998. Identification and disruption of a plant shaker-like outward channel involved in $\mathrm{K}^{+}$release into the xylem sap. Cell 94, 647-55.

Hampton, C., Broadley, M., White, P., 2005. Short review: the mechanisms of radiocaesium uptake by Arabidopsis roots. Nukleonika 50, 3-8.

Haruta, M., \& Sussman, M.R., 2012. The effect of a genetically reduced plasma membrane protonmotive force on vegetative growth of Arabidopsis. Plant Physiol. 158, 1158-71.

Hedrich, R., 2012. Ion channels in plants. Physiol. Rev. 92, 1777-811.

Hirsch, R.E., Lewis, B.D., Spalding, E.P., Sussman, M.R., 1998. A role for the AKT1 potassium channel in plant nutrition. Science $\mathbf{2 8 0}, 918-21$.

Kanter, U., Hauser, A., Michalke, B., Dräxl, S., Schäffner, A.R., 2010. Caesium and strontium accumulation in shoots of Arabidopsis thaliana: genetic and physiological aspects. J. Exp. Bot., erq213.

Kobayashi, D., Uozumi, N., Hisamatsu, S.I., Yamagami, M., 2010. AtKUP/HAK/KT9, a K+ transporter from Arabidopsis thaliana, mediates Cs+ uptake in Escherichia coli. Biosci. Biotech. Biochem. 74, 203-5.

Kobayashi, D., Okouchi, T., Yamagami, M., Shinano, T., 2014. Verification of radiocesium decontamination from farmlands by plants in Fukushima. J. Plant Res. 127, 51-6.

Kochian, L.V., \& Lucas, W.J., 1982. Potassium transport in corn roots I. Resolution of kinetics into a saturable and linear component. Plant Physiol. 70, 1723-31.

Lacombe, B., Pilot, G., Michard, E., Gaymard, F., Sentenac, H., Thibaud, J.-B., 2000. A shaker-like K+ channel with weak rectification is expressed in both source and sink phloem tissues of Arabidopsis. Plant Cell 12, 837-51.

Mäser, P., Thomine, S., Schroeder, J.I., Ward, J.M., Hirschi, K., Sze, H., Talke, I. N., Amtmann, A., Maathuis, F.J.M., Sanders, D., Harper, J.F., Tchieu, J., Gribskov, M., Persans, M.W., Salt, D.E., Kim, S.A., Guerinot, M.L., 2001. Phylogenetic relationships within cation transporter families of Arabidopsis. Plant Physiol. 126, 1646-67. 
471 Murashige, T., \& Skoog, F., 1962. A revised medium for rapid growth and bio assays with tobacco 472 tissue cultures. Physiol. Plant. 15, 473-97.

473 Pilot, G., Gaymard, F., Mouline, K., Chérel, I., Sentenac, H., 2003. Regulated expression of 474 Arabidopsis Shaker $\mathrm{K}+$ channel genes involved in $\mathrm{K}+$ uptake and distribution in the plant. Plant 475 Mol. Bio. 51, 773-87.

476 Qi, Z., Hampton, C.R., Shin, R., Barkla, B.J., White, P.J., Schachtman D.P., 2008. The high affinity K+ 477 transporter AtHAK5 plays a physiological role in planta at very low $\mathrm{K}+$ concentrations and provides 478 a caesium uptake pathway in Arabidopsis. J. Exp. Bot. 59, 595-607.

479 Rubio, F., Guillermo, E., Rodríguez-Navarro, A., 2000. Cloning of Arabidopsis and barley cDNAs 480 encoding HAK potassium transporters in root and shoot cells. Physiol. Plant. 109, 34-43.

481 Rubio, F., Nieves-Cordones, M., Alemán, F., Martínez, V., 2008. Relative contribution of AtHAK5 and 482 AtAKT1 to K+ uptake in the high-affinity range of concentrations. Physiol. Plant. 134, 598-608.

483 Sacchi, G.A., Espen, L., Nocito, F., Cocucci, M., 1997. Cs ${ }^{+}$uptake in subapical maize root segments: 484 Mechanism and effects on $\mathrm{H}+$ release, transmembrane electric potential and cell $\mathrm{pH}$. Plant Cell 485 Physiol. 38, 282-9.

486 Shaw, G., \& Bell, J., 1989. The kinetics of caesium absorption by roots of winter wheat and the 487 possible consequences for the derivation of soil-to-plant transfer factors for radiocaesium. J. $488 \quad$ Environ. Radioact. 10, 213-31.

489 Smolders, E., Kiebooms, L., Buysse, J., Merckx, R., 1996. 137Cs uptake in spring wheat (Triticum 490 aestivum L. cv. Tonic) at varying K supply. Plant Soil 181, 211-20.

491 Waegeneers, N., Camps, M., Smolders, E., Merckx, R., 2001. Genotypic effects in phytoavailability of 492 radiocaesium are pronounced at low K intensities in soil. Plant Soil 235, 11-20.

493 White, P.J., \& Broadley, M.R., 2000. Tansley Review No. 113. New Phytol. 147, 241-56.

494 White, P.J., \& Davenport, R.J., 2002. The voltage-independent cation channel in the plasma 495 membrane of wheat roots is permeable to divalent cations and may be involved in cytosolic Ca2+ 496 homeostasis. Plant Physiol. 130, 1386-95.

497 Zhu, Y.-G., Shaw, G., Nisbet, A., Wilkins, B., 1999. Effects of external potassium supply on 498 compartmentation and flux characteristics of radiocaesium in intact spring wheat roots. Ann. Bot. 499 84, 639-44. 
500 Zhu, Y.-G., \& Smolders, E., 2000. Plant uptake of radiocaesium: a review of mechanisms, regulation $501 \quad$ and application. J. Exp. Bot 51, 1635-45.

502 Zhu, Y.-G., Shaw, G., Nisbet, A., Wilkins, B., 2000. Effect of potassium starvation on the uptake of 503 radiocaesium by spring wheat (Triticum aestivum cv. Tonic). Plant Soil 220, 27-34.

504 Zhu, Y.-G., 2001. Effect of external potassium (K) supply on the uptake of 137 Cs by spring wheat 505 (Triticum aestivum cv. Tonic): a large-scale hydroponic study. J. Environ. Radioact. 55, 303-14.

506

507 
Table 1: Experimental scheme.

\begin{tabular}{llc}
\hline \multicolumn{1}{c}{ Step } & \multicolumn{1}{c}{ Composition of the medium } & \multicolumn{1}{c}{ Duration } \\
\hline $1-$ Growing on agar plates & MS $1 / 2,1 \%$ agar, $1 \%$ sucrose & 7 days \\
2- Growing on sand & Watered with nutrient solution & 14 days \\
3- Growing in hydroponics & Nutrient solution & $3-5$ days \\
4- $\mathrm{K}^{+}$-treatment in hydroponics & $\mathrm{K}^{+}$-treatment solution & 5 days \\
$\begin{array}{l}\text { 5a- Exposure to } \mathrm{Cs}^{+} \text {(short-term } \\
\text { experiments) }\end{array}$ & $\mathrm{K}^{+}$-treatment solution $+{ }^{133} \mathrm{Cs}(0.1-3000 \mu \mathrm{M})$ & 15 min to $6 \mathrm{~h}$ \\
$\begin{array}{l}\text { 5b- Exposure to } \mathrm{Cs}^{+} \text {(long-term } \\
\text { experiments) }\end{array}$ & ${ }^{137} \mathrm{Cs}$ & 7 days \\
\hline
\end{tabular}

509 
511 Table 2: Fresh-weight (FW) and $\mathrm{K}^{+}$content of roots and shoots of Col-0 depending on the $\mathrm{K}^{+}-$

512 treatment. Plants were grown 7 days on MS1/2, 14 days on sand then 8 days in hydroponic system.

$513 \mathrm{~K}^{+}$-treatments were applied during the last 5 days of the hydroponic step. Values are means of at least

514 ten plants with standard deviation in brackets. To evaluate the effect of $\mathrm{K}^{+}$-treatment, ANOVA analysis

515 was performed on fresh-weight then on $\mathrm{K}^{+}$content separately and results are indicated in the last line

516 (NS, Non-Significant and ${ }^{* *},{ }^{* *}$ Significant at the $\alpha=0.01$ and 0.001 level respectively). Different

517 letters in bold indicate significant differences between means (Tuckey post-hoc test, p-value $<0.05$ ).

518

\begin{tabular}{lcccc}
\hline $\mathrm{K}^{+}$-treatment $(\mu \mathrm{M})$ & Shoots $(\mathrm{g})$ & Roots $(\mathrm{g})$ & $\begin{array}{c}\text { K shoots } \\
\left(\mu \mathrm{mol} . \mathrm{g}^{-1} \mathrm{FW}\right)\end{array}$ & $\begin{array}{c}\text { K roots } \\
\left(\mu \mathrm{mol} . \mathrm{g}^{-1} \mathrm{FW}\right)\end{array}$ \\
\hline 10 & $0.331(0.166) \mathbf{N S}$ & $0.107(0.060) \mathbf{N S}$ & $50.64(9.55) \mathbf{a}$ & $60.48(15.15) \mathbf{a}$ \\
100 & $0.280(0.176) \mathbf{N S}$ & $0.129(0.094) \mathbf{N S}$ & $65.70(18.58) \mathbf{b}$ & $73.13(29.69) \mathbf{a}$ \\
3000 & $0.363(0.176) \mathbf{N S}$ & $0.135(0.056) \mathbf{N S}$ & $69.18(17.89) \mathbf{b}$ & $109.03(10.56) \mathbf{b}$ \\
$\mathrm{K}^{+}$-treatment effect & NS & NS & $* \star$ & $* \star \star \star$ \\
\hline
\end{tabular}

519

520 


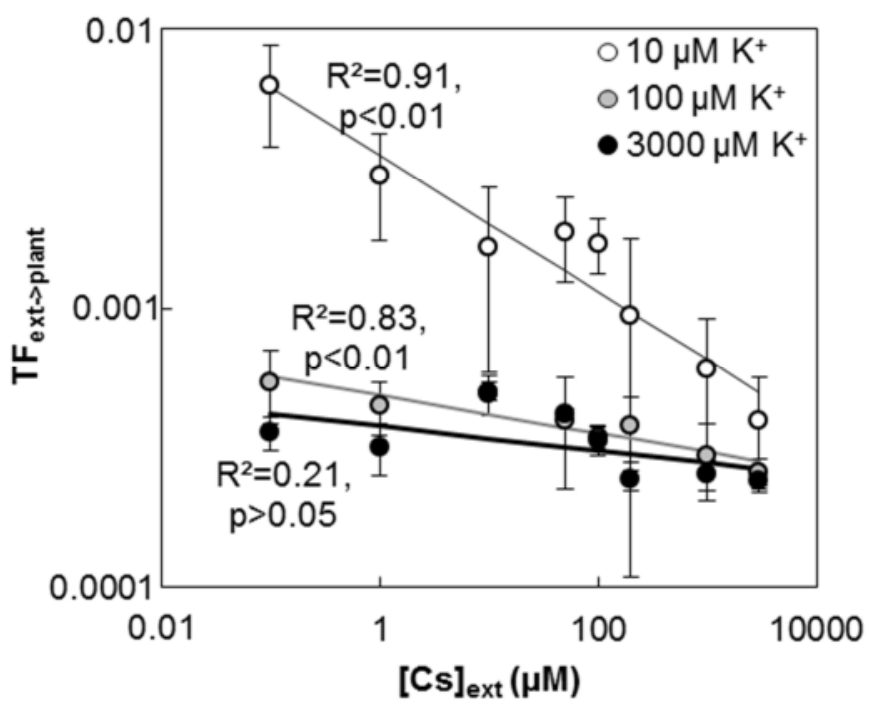

521

522 Figure 1: Log-log plot of transfer factor $\left(T F_{\text {ext } \rightarrow \text { plant }}\right)$ of $\mathrm{Cs}^{+}$for Col-0 grown with three different $523 \mathrm{~K}^{+}$-treatments $(10,100$ or $3000 \mu \mathrm{M})$ and exposed during $15 \mathrm{~min}$ to a range of $\mathrm{Cs}^{+}$ 524 concentrations. Transfer factor was calculated as described in Eq.(1). Values are means of at least 525 three different plants and error bars indicate standard deviation. 

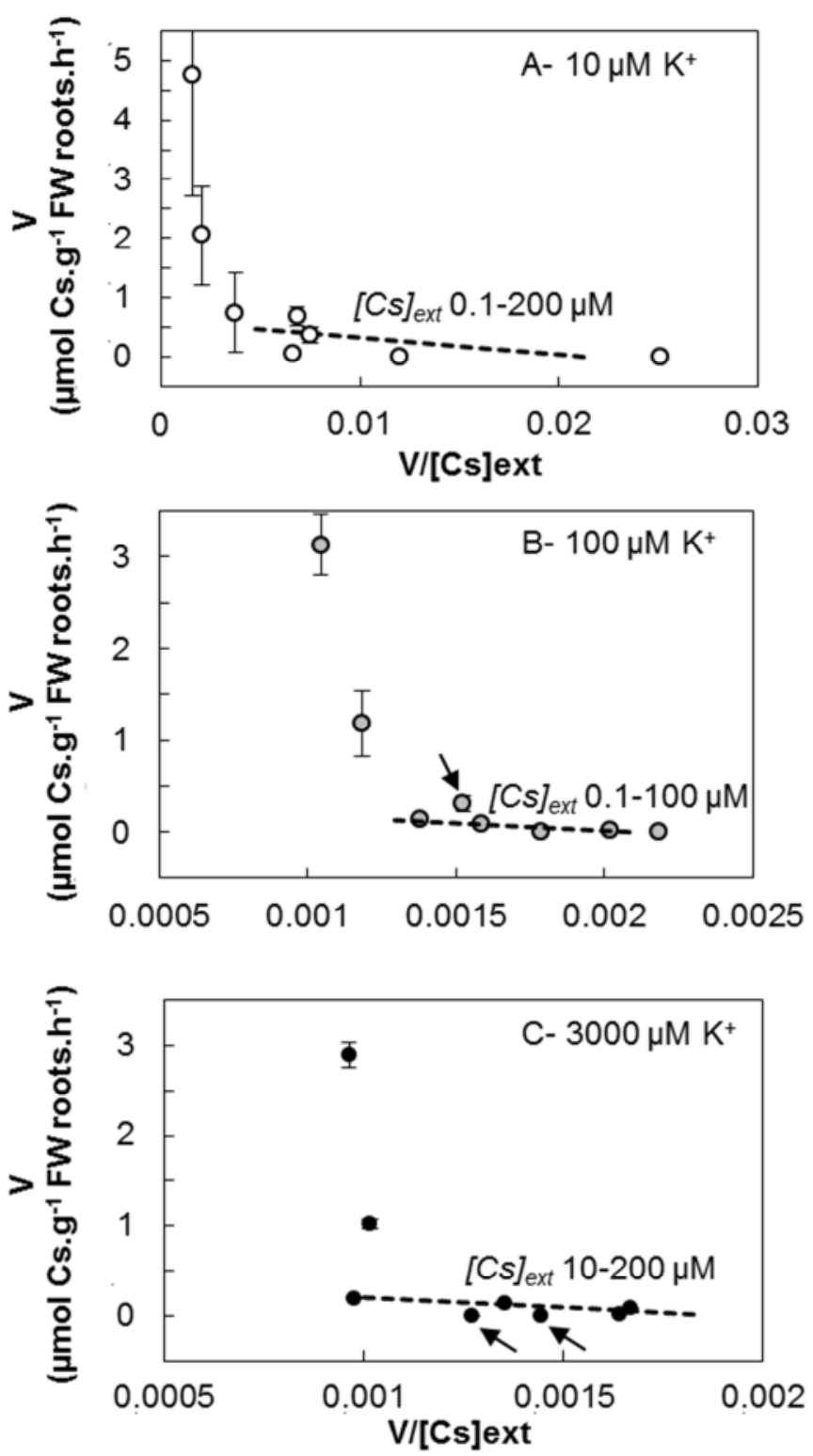

528 Figure 2: Eadie-Hofstee plot for $\mathrm{Cs}^{+}$uptake data from 15 min influx assays. Plants were supplied

529 with three distinct $\mathrm{K}^{+}$-treatments $(\mathrm{A}-10 \mu \mathrm{M}, \mathrm{B}-100 \mu \mathrm{M}, \mathrm{C}-3000 \mu \mathrm{M})$. Concentrations of $\mathrm{Cs}^{+}$in the

530 exposure solution range from 0.1 to $3000 \mu \mathrm{M}$. Values are means of at least three different plants and

531 error bars indicate standard deviation. Broken lines represent the Michaelis-Menten function with

532 kinetics parameters calculated in Table 3. Linear regression is calculated over the range of external

$533 \mathrm{Cs}^{+}$concentrations $\left([\mathrm{Cs}]_{\text {ext }}\right)$ indicated on each figure. Arrows indicate extreme values which had to be

534 removed from the calculation because they lead to absurd results. 
536 Table 3: Estimation of $\mathrm{Cs}^{+}$influx kinetic parameters using Eadie-Hofstee plot for data from 15

537 min influx assays. Uncertainties on parameters estimation by linear regression are indicated in 538 brackets. In order to avoid absurd results for kinetics parameters, some extreme external $\mathrm{Cs}^{+}$ 539 concentrations $\left([C s]_{e x t}\right.$ in the table) had to be removed of the linear regression. The $\mathrm{R}^{2}$ values are 540 associated with the linear regression represented in Figure 2 (broken lines).

541

\begin{tabular}{lrlcl}
\hline $\mathrm{K}^{+}$-treatment $(\mu \mathrm{M})$ & {$[C s]_{\text {ext }}(\mu \mathrm{M})$} & $K_{m}(\mu \mathrm{M})$ & $V_{\max }\left(\mu \mathrm{mol} . \mathrm{g}^{-1} \mathrm{FW}\right.$ roots. $\left.\mathrm{h}^{-1}\right)$ & $\mathrm{R}^{2}$ \\
\hline 10 & $0.1-200$ & $28.68(16.85)$ & $0.61(0.21)$ & 0.42 \\
100 & $0.1-100$ & $163.48(49.68)$ & $0.34(0.09)$ & 0.78 \\
3000 & $10-200$ & $214.94(70.03)$ & $0.41(0.10)$ & 0.99 \\
\hline
\end{tabular}

542 
A-15 min exposure
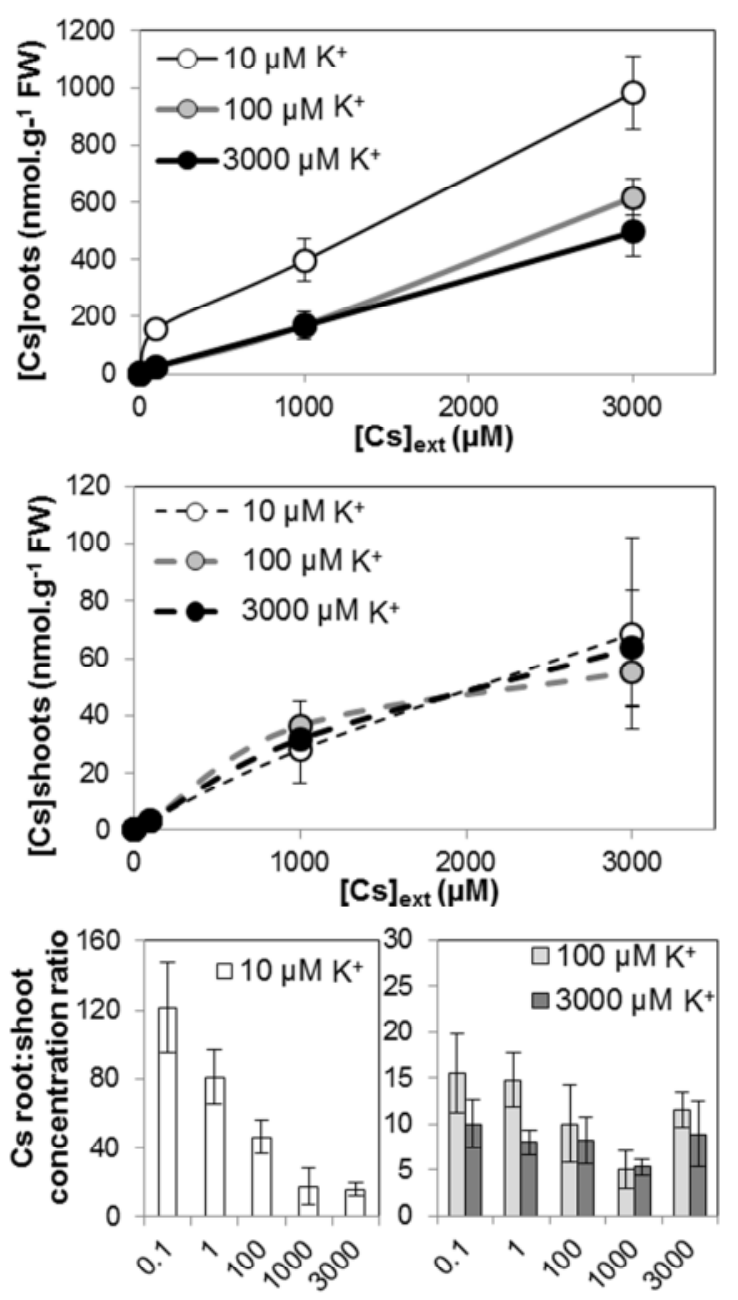

$[\mathrm{Cs}]_{\text {ext }}(\mu \mathrm{M})$

$[\mathrm{Cs}]_{\text {ext }}(\mu \mathrm{M})$
B- $6 \mathrm{~h}$ exposure
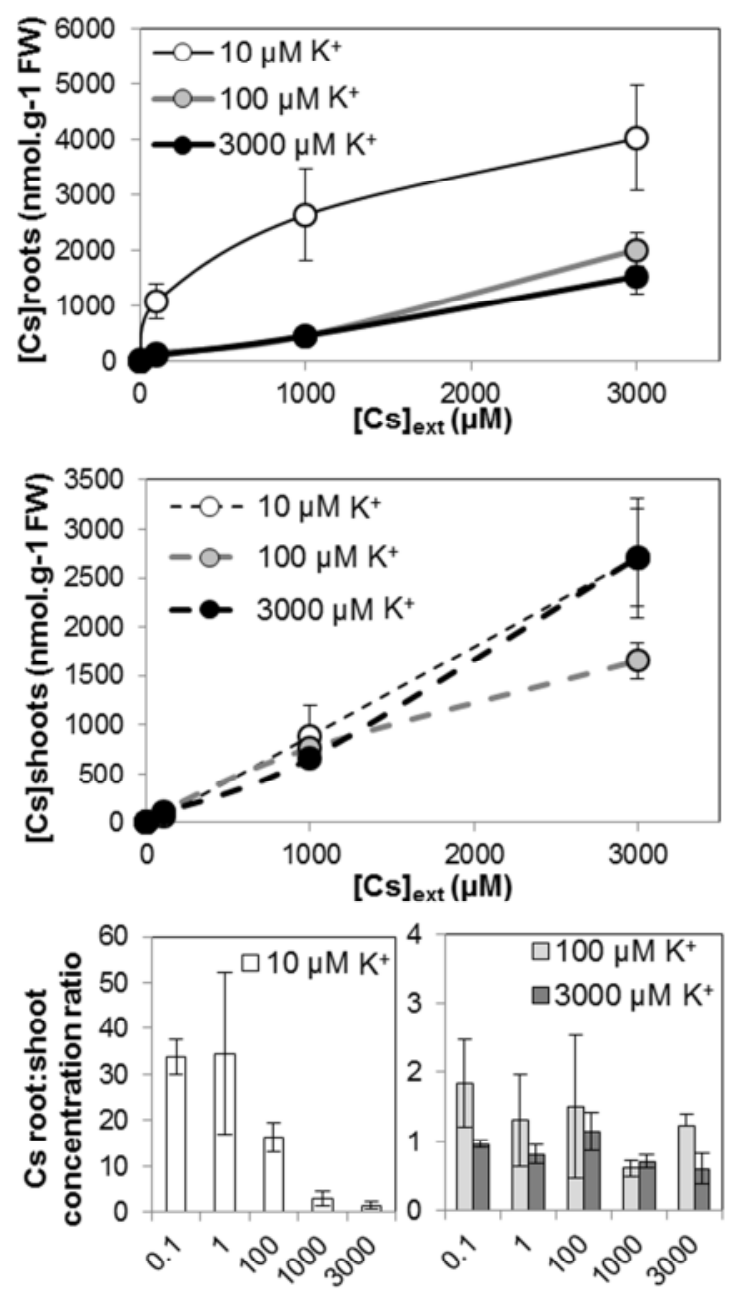

$[\mathrm{Cs}]_{\text {ext }}(\mu \mathrm{M})$

$[\mathrm{Cs}]_{\text {ext }}(\mu \mathrm{M})$

Figure 3: Evolution of the distribution of $\mathrm{Cs}^{+}$between roots and shoots across a range of

$545[\text { Cs }]_{\text {ext }}$ for plants from the short-term influx assays. Three distinct $\mathrm{K}^{+}$-treatments $(10 \mu \mathrm{M}, 100 \mu \mathrm{M}$,

$5463000 \mu \mathrm{M} \mathrm{K}^{+}$) were applied during 5 days before exposure to $\mathrm{Cs}^{+}$. Levels of $\mathrm{K}^{+}$in the pre-culture were

547 maintained during the exposure to $\mathrm{Cs}^{+}$. Plants were exposed during A- 15 min or during B- $6 \mathrm{~h}$. Means of at least three different plants are represented with standard deviation. 
550 Table 4: $\mathrm{Cs}^{+}$accumulation in Col-0 exposed during 7 days to nutrient solution containing $1 \mu \mathrm{M}$

$551 \mathrm{Cs}^{+}$and three distinct $\mathrm{K}^{+}$concentrations. $\mathrm{DF}(\mathrm{Cs})$ is the discrimination factor calculated for $\mathrm{Cs}^{+}$with

552 Eq.(3). Values are mean of at least six different plants with standard deviation in brackets. Result of

553 the ANOVA analysis is indicated in the last line. Different letters in bold indicate significant differences

554 between means (Tuckey post-hoc test, $p$-value $<0.05$ ).

555

\begin{tabular}{lcccc}
\hline $\begin{array}{c}\mathrm{K}^{+} \text {-treatment } \\
(\mu \mathrm{M})\end{array}$ & $\begin{array}{c}\mathrm{Cs}^{+} \text {shoot } \\
\left(\mathrm{nmol} \mathrm{g}^{-1} \mathrm{FW}\right)\end{array}$ & $\begin{array}{c}\mathrm{Cs}^{+} \text {roots } \\
\left(\mathrm{nmol}^{-1} \mathrm{FW}\right)\end{array}$ & $\begin{array}{c}\mathrm{Cs}^{+} \text {whole plant } \\
\left(\mathrm{nmol} \mathrm{g}^{-1} \mathrm{FW}\right)\end{array}$ & Plant $\mathrm{FF}(\mathrm{Cs})$ \\
\hline 10 & $0.34(0.04) \mathbf{a}$ & $3.08(0.60) \mathbf{a}$ & $0.98(0.10) \mathbf{a}$ & $0.37(0.06) \mathbf{~ a}$ \\
100 & $0.17(0.02) \mathbf{b}$ & $0.28(0.08) \mathbf{b}$ & $0.21(0.03) \mathbf{b}$ & $0.54(0.08) \mathbf{b}$ \\
3000 & $0.01(0.0007) \mathbf{c}$ & $0.01(0.002) \mathbf{c}$ & $0.01(0.0006) \mathbf{c}$ & $0.54(0.03) \mathbf{b}$ \\
$\mathrm{K}^{+}$-treatment effect & $* * *$ & $* * *$ & $* * *$ & $* * *$ \\
\hline
\end{tabular}

556 
$\square \mathrm{K}^{+}$distribution before exposure to $\mathrm{Cs}^{+}$

$\square \mathrm{K}^{+}$distribution after exposure to $\mathrm{Cs}^{+}$

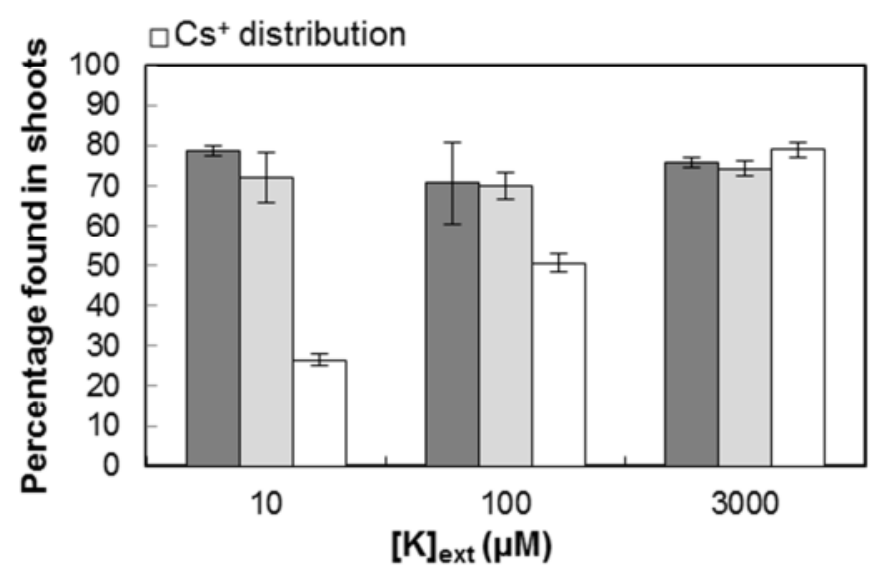

558 Figure 4: Comparison between $\mathrm{K}^{+}$and $\mathrm{Cs}^{+}$distribution in plants exposed during 7 days to a

559 nutrient solution containing $1 \mu \mathrm{M} \mathrm{Cs}{ }^{+}$and three distinct $\mathrm{K}^{+}$concentrations. Percentage was

560 calculated by dividing the quantity of element found in shoots by the quantity found in the whole plant.

$561 \mathrm{~K}^{+}$distribution before exposure to $\mathrm{Cs}^{+}$was measured on non-exposed plants from the same bulk than

562 plants used for the $\mathrm{Cs}^{+}$exposure assay. Means of at least four different plants are represented with

563 standard deviation. 


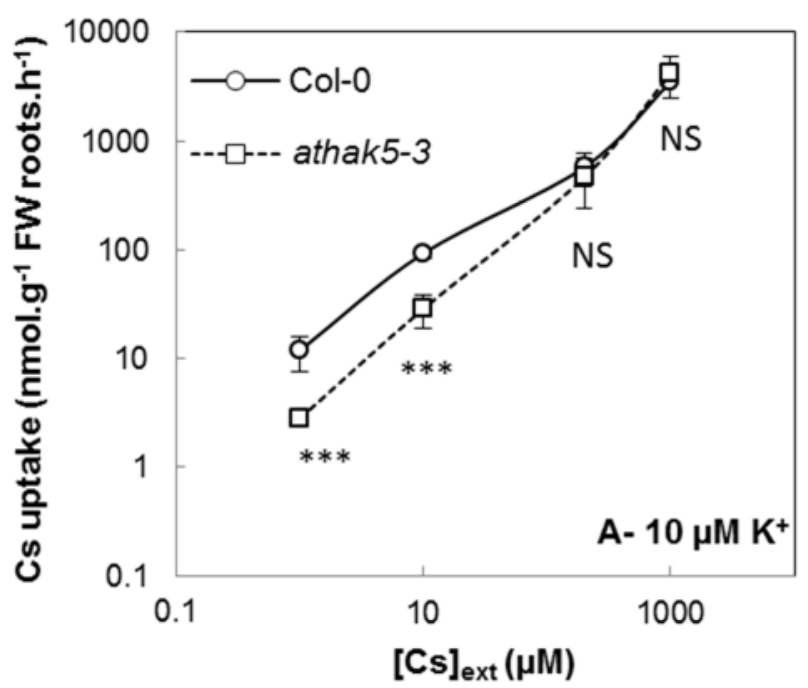

565

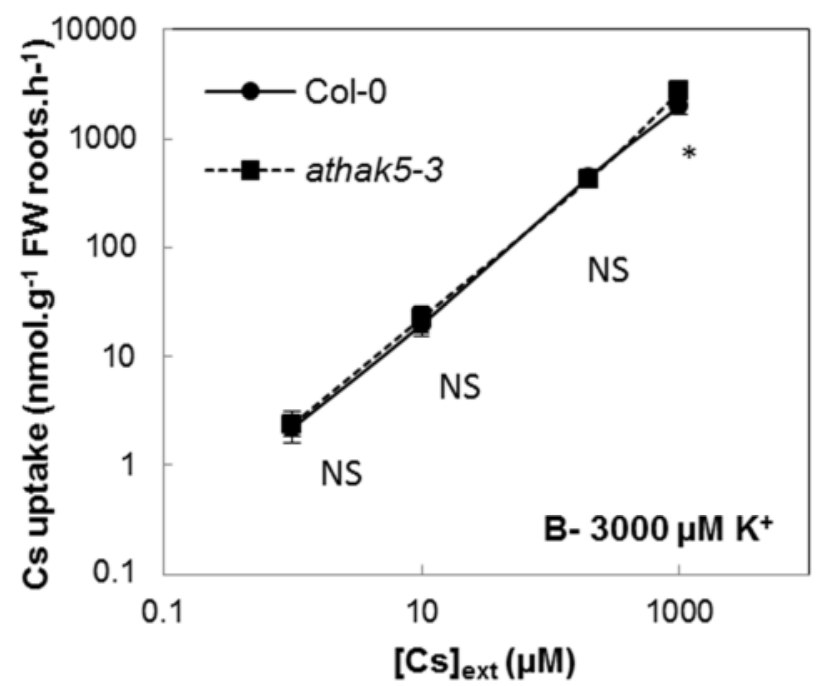

566

567 Figure 5: $\mathrm{Cs}^{+}$uptake measured over $15 \mathrm{~min}$ for the wild-type Col-0 and the mutant line athak5-3.

568 Two distinct levels of $\mathrm{K}^{+}$were used during pre-culture and during exposure to $\mathrm{Cs}^{+}: \mathrm{A}-10 \mu \mathrm{M}$ and $\mathrm{B}$ -

$5693000 \mu \mathrm{M}$. Means of at least five different plants are represented with standard deviation. Student t-

570 tests were performed to compare $\mathrm{Cs}^{+}$uptake between hak5-3 and Col-0 for each [Cs $]_{\text {ext }}$ (NS, Non-

571 significant and ${ }^{*},{ }^{* * *} \mathrm{P}<0.05$ and $\mathrm{P}<0.001$ respectively).

572 